\title{
ARTICLE
}

https://doi.org/10.1057/s41599-019-0286-x

\section{Fathers, sons, and monsters: Rousseau, Blake, and Mary Shelley}

Joshua Schouten de Jel ${ }^{1}$

\begin{abstract}
Through their reading of Jean-Jacques Rousseau, William Blake, and Mary Shelley arrive at a similar formula for their respective texts: the mismanagement, neglect, and eventual abandonment of children by their fathers catalyses the development of monstrous progeny in Shelley's Frankenstein (1818/31), Blake's Tiriel (1789), The Book of Urizen (1794), and The Four Zoas (1795-1804). In particular, both Blake and Shelley pick up on Rousseau's concerns about the mishandling of children's bodies as part of contemporary nursing practices in Émile, as well as the way in which the vision of a self-led educational programme is continually undermined by the fear of pedagogical mismanagement. While Blake and Shelley are rarely brought together in critical discussions, this paper, by looking specifically at the physical and psychological formation of children within the context of father-son relationships, hopes to provide an analytical key which will unlock the way both Romantic writers incorporated personal, pedagogical, and philosophical material from Rousseau in their familyorientated texts.
\end{abstract}

\footnotetext{
${ }^{1}$ Plymouth University, Plymouth, UK. Correspondence and requests for materials should be addressed to J.S.d J. (email: joshua.schoutendejel@plymouth.ac.uk)
} 


\section{Introduction}

M ary Shelley was well acquainted with the pedagogical and political philosophy of Jean-Jacques Rousseau: she had read Julie; or the New Eloise (1761), Emile; or, On Education (1762), Essays on the Origin of Languages (1781), and his Confessions Part 1 (1782) and Part 2 (1789). ${ }^{1}$ In fact, Shelley had read Rousseau's Confessions just a year before commencing Frankenstein (1818/1831), ${ }^{2}$ with her journal entries revealing that she continued to reread parts of this 'invaluable book.' She was not alone: Rousseau's influence is tangible in the works of the first-generation Romantic poets William Wordsworth and Samuel Taylor Coleridge as well as the 'Villa Diodati' group. ${ }^{3}$

William Blake was equally familiar with the Genevan philosopher's works, ${ }^{4}$ though less receptive. ${ }^{5}$ First mentioned in The Song of Los (1795) and then again in Milton (1804-11) ${ }^{6}$ and Jerusalem (1804-20), ${ }^{7}$ he is subject to persistent ridicule with Blake condemning 'The Book written by Rousseau calld his Confessions [a]s an apology \& cloke for his sin \& not a confession' ( 738 iii.52.53-5). Among the Romantics such vitriol is certainly singular, yet Mary Shelley did not read Rousseau's work without misgivings. In fact, it is remarkable how similarly Shelley and Blake view Rousseau's abandonment of his children in Confessions and how they subsequently deal with father-son relationships in their respective prose and poetry. ${ }^{8}$

This thematic concern has, however, remained largely unaddressed. As late as the beginning of the twenty-first century, Mark Lussier could comment that William Blake and Mary Shelley were 'two writers rarely brought into critical coincidence' (2000, p. 166). In part, this is because they provide such convenient chronological bookends to Romantic investigations. ' Even so, when they are brought together, The Book of Urizen (1794) is generally the only Blakean text read alongside Frankenstein. ${ }^{10}$ The common exegesis then bifurcates along the following modes of enquiry: either claiming that Urizen, by isolating himself and creating the world according to an Enlightenment blueprint, is a prototypal Frankenstein figure; or, that the attempt made by Frankenstein's creature to find a mate mirrors the ontological division into Emanations and Spectres. ${ }^{11}$

Blake and Shelley's familiarity with Rousseau, coupled with Rousseau's preoccupation with pedagogy and phylogeny, provides an additional interpretative key for a cross-textual analysis. ${ }^{12}$ Specifically, Rousseau's concern about the mishandling of children's bodies as part of contemporary nursing practices in Emile, as well as the way in which his vision of a self-led educational programme is continually undermined by the fear of pedagogical mismanagement, can be read as the practical context, which frames the monstrous relationships between Tiriel and his children in Blake's Tiriel (1789), Los and his son, Orc, in The Book of Urizen and The Four Zoas (1795-1804), as well as Alphonse and his son, Victor, and Victor and his surrogate son, the creature, in Shelley's Frankenstein. By moving beyond the standard Urizen/Frankenstein axis, there is scope to explore these monstrous parental dynamics.

Rousseau's contribution to the eighteenth-century pedagogical revolution was part of a wider reform movement, which had sprung up during the mid-seventeenth-century. ${ }^{13}$ Building upon the philosophical groundwork of the Spanish humanist Juan Luis Vives, ${ }^{14}$ Francis Bacon, ${ }^{15}$ Descartes, ${ }^{16}$ and the Czech philosopher Jan Comenius, ${ }^{17}$ the 1640 s alone saw educational tracts published in England by Hezekiah Woodward, John Milton, ${ }^{18}$ William Petty, John Dury, and John Hall. By the end of the century, John Locke would publish his influential Some Thoughts Concerning Education (1693).

In Some Thoughts, Locke begins by warning that 'The little, and almost insensible Impressions on our tender Infancies, have very important and lasting Consequences' and 'that of all the Men [...] Nine parts of Ten are what they are, Good or Evil, useful or not, by their Education' (p. 2). Far from being born with an innate disposition, temperament is shaped by the pedagogue. The child's impressionability is further emphasised through Locke's description of how the 'gentle application of the hand turns the flexible Waters' of the child's mind 'into Chanels, that make them take quite contrary Courses.' The thematic principle of the tabula rasa-which posits that the new-born's mind is a blank slate, a 'white Paper, or Wax, to be moulded and fashioned as one pleases' (p. 261)-permits the pedagogue to intellectually form the mind and thereby create, as it were, the child anew.

Such was the success of Locke's pedagogical philosophy that it permeated eighteenth-century culture. The Tatler no. 181 (6th June 1710), for instance, stressed that 'the mind in infancy' was 'like the body in embryo, and receives impressions so forcible, that they are as hard to be removed [...] as any mark, with which the child is born' (1822, p. 391). The Female Spectator no. 21 (1745) similarly adhered to the Lockean belief that an adult's moral state is subject to its formative development in childhood (Haywood, 1999, p. 263). While The Spectator no. 215 (6th November 1711) compared the child to unpolished marble,

which shews none of its inherent beauties, until the skill of the polisher [i.e., pedagogue] fetches out the colours, makes the surface shine, and discovers every ornamental cloud, spot and vein that runs through the body of it (1776, p. 202).

As a result, '[e]ducation [...] when it works upon a noble mind, draws out to view every latent virtue and perfection, which without such helps are never able to make their appearance' (pp. $202-3) .{ }^{19}$

Rousseau sustains this interests by appropriating parts of Locke's philosophy in Émile. ${ }^{20}$ Rousseau agrees, for example, that the objects a child is shown has a significant impact upon his intellectual and emotional development (1918, p. 27); distinguishing, furthermore, between ideas, memory, and sensations in the application of definite ideas to signs (p. 78), which grounds Locke's An Essay Concerning Human Understanding (1689). Similarly, in his description of how nurses bind and mould infants' heads, Rousseau captures the mid-eighteenth-century scientific development of the tabula rasa:

It is said that nurses sometimes pretend to give the heads of infants a more proper form by a sort of moulding; and we suffer them to do this! It seems that our heads were badly fashioned by the Author of Nature, and that they need to be made over, outwardly by nurses and inwardly by philosophers! (p. 10).

Nature has produced a human frame, which corresponds to the requirements of the human mind-a key condition in the privileging of 'natural man [a]s complete in himself (p. 5)-but mankind, in an attempt to improve upon nature's design, refashions the child's body and thereby impoverishes the mental capacities, which are, at a later date, further bent and warped by proselytising philosophers.

In a semantic shift from the 'outwardly' physical to the 'inwardly' psychological, Rousseau evidences a thematic concern - which Locke addresses as well, admitting that while 'our main care should be about the inside, yet the clay Cottage is not to be neglected' (1693, p. 2)-for his entire treatise: the malformation of the child's body directly relates to the intellectual stunting of cognitive development.

What's more, Rousseau believed that the infant, as soon as he is born, begins to learn from those around him and from the objects he is shown. It therefore follows if the first attentive adult is a 
nurse, then 'our first teacher is our nurse' (p. 9). Not only can the nurse deform the infant body, but she also has the capacity to deform the infant's mind. Later in Book 1, Rousseau attempts to mitigate the nurse's role by suggesting that the infant, '[b]efore he can speak, before he can understand, [...] is already instructing himself' and that 'the moment he knows his nurse he has already acquired much knowledge' (p. 25). This a-posteriori epistemology is based upon Rousseau's prioritisation of experience-the infant's interaction with people and objects and his ability 'to seek or to shun' that which produces 'our sensations' (p. 4) -over pedagogical nurture. However, if the nurse determines the freedom of the infant's body and, subsequently, the experiences available to the infant, then the nurse determines physical, as well as mental well-being.

This is why Rousseau is alarmed by the 'inaction and constraint imposed on the limbs of a child,' such as swaddling, because it 'prevent[s] him from growing strong, and weaken[s] his constitution' (pp. 10-1). Instead, Rousseau celebrates those countries where 'extravagant precautions are not taken' because this creates a cohort of 'men [who] are all tall, strong, and well-proportioned'; in his own country, where children suffer from injurious nursing practices, there are 'swarms [of] the hump-packed, the lame, the knock-kneed, and the sickly-with all sorts of patched-up men' (p. 11).

While nature produces healthy and robust constitutions, the nurse and the pedagogue interfere and disrupt the physiological and psychological harmony: ' $[\mathrm{t}] \mathrm{o}$ form this rare creature, what have we to do? Much, doubtless, but chiefly to prevent anything from being done' (pp. 7-8). Rousseau describes unnecessary interference as 'hasten[ing] to deform it [the body] in a press'the metaphor is repeated (p. 91)-and of creating a situation, which is 'more unfortunate than a criminal in chains' (p. 11). The visceral language further highlights the interrelationship between somatic inhibition and mental degeneration. William Blake succinctly encapsulates this phenomenon by utilising Rousseau's penal metaphor in 'London' when describing those 'mind-forg'd manacles' (SE 128 8), while Rousseau himself, in The Reveries of the Solitary Walker, is also befittingly reminded of the abandonment of his own children while hearing about the malevolence of criminals (1992, p. 123).

Rousseau fathered five children with Thérèse Levasseur, his domestic partner, but left them all to a Paris orphanage. Although this was not an uncommon practice among the newly monied middle classes (Fuchs, 1984, pp. 63-4), Rousseau unconvincingly attempts to justify himself by invoking Plato's proposal that children would benefit from state education: 'I truly saw no harm in it. Taken all in all, I chose for my children what was best for them, or what I believed to be so' $(2000$, p. 348$) .^{21}$ The reality of an eighteenth-century orphanage differed significantly from Rousseau's utopian expectations. As Patrick Coleman notes, '[a] lthough survival prospects for children entrusted to foundling homes were not good, many people wanted to believe them better than they actually were' (2000, xviii). Rousseau's equivocation that he did what was best for his children, 'or what $I$ believed to be so' (emphasis added), can be read as such an admission. ${ }^{22}$

While Rousseau launches a staunch defence of his own 'true feelings of justice' at the end of Confessions, concluding that '[n] ever for a single moment in his life could Jean-Jacques have been without sentiment, without pity, an unnatural father' (2000, p. 347), his profound sense of guilt resurfaces in Reveries. During the eulogy of Mme Geoffrin, Rousseau's thoughts wander to his own children as Monsieur P. 'turned on the pleasure that Mme G. took in seeing children':

[He] accused all those who did not have the same fondness of having a bad natural temperament and of being wicked
- to the point of saying that if those being led to the gallows or to the torture wheel were to be asked about it, all would acknowledge they had not loved children (1992, p. 123).

The next day, while walking to École-Militaire, Rousseau reflects that 'the sole pretext of bringing this brochure to me' was because 'I had placed my children in the foundling home.' Rousseau (sub)consciously associates his own actions with that of the criminals, for he objects to being 'misrepresent[ed] [...] as an unnatural father [...who] evidently hated children.'

In Émile, it appears that Rousseau's decision to employ chains as signifiers of mental incarceration (1918, p. 44) and tyrannical preceptors (p. 87) is bound up with his ideas of fatherhood. The adoption of such a consistent rhetorical technique is not simply evidence for the metaphorical elucidation of pedagogical observations but, rather, a deliberate emphasis on the epistemological symbiosis of physiology and psychology. It is systematically reinforced throughout Emile, with Rousseau habitually relying on such formulations when reprimanding the careless pedagogue: it is not the criminal who should be hung, but he who compels him to become such' (p. 174).

Rousseau may have had another personal circumstance in mind. Recognising the role formative ideas 'sown [...] during childhood' have upon an adult's character, Rousseau recalls at the beginning of Confessions how much his older brother suffered as a result of inattention and neglect $\left(2000\right.$, pp. 9-10). ${ }^{23}$ The phylogeny of family life in Confessions builds upon the pedagogical foundations of Émile, but there is also an interesting anthropological echo here of the development of natural man into a social being which preoccupied his Discourse and which he continued to address in The Social Contract (1762). Rousseau is clearly aware of the paternal pedagogue's role in leading his charge away from the 'dissolute ways' (p. 9) that befell his brother and towards his own 'seed[s] of heroism and virtue, which my father and my fatherland and Plutarch had sown there during my childhood' (p. 346).

The physical, intellectual, as well as moral development of the child is bound up with the care taken by the paternal pedagogue. In Emile, Rousseau warns that, from birth, the child should be incorporated within the filial fold to ensure the successful promotion of healthy proportions and passions:

Would you, then, have him preserve his original form? Guard it from the moment of the child's birth. As soon as born take possession of him, and do not give him up until he is a man... As the real nurse is the mother, the real preceptor is the father (1918, p. 15).

Although Rousseau is not advocating physical interference, he does expound the need to protect the human frame: 'let the child pass from the hands of one [the mother] into the hands of the other [the father].' As Adriana Benzaquen notes, the eighteenthcentury demanded of parents a 'new responsibility' to ensure the child's well-being, 'for the child's own sake, for the sake of the family and for the sake of the state' (2006, p. 24).

The private, familial space became child-orientated-one might say child-dominated-with the parents' time specifically directed towards developing their offspring. Rousseau's figurative language exemplifies the tactility of such pedagogy; and, with the concerns previously expressed regarding the malformation of infant bodies in mind, Rousseau now begins to amalgamate these concerns with parenthood.

For instance, when defining the father's role, Rousseau evokes the biblical parallel of God forming Adam from clay: 'A teacher! What an exalted soul he should be! In truth, to form a man, one must be either a father or more than a man' (pp. 16-7). ${ }^{24}$ The father/Father, prefiguring the imagery with which Victor 
Frankenstein imbues his own creative task in Frankenstein (2003, p. 55), must therefore 'form a man' correctly, avoiding costly errors:

if Nature gives to a child's brain that plasticity, which renders it capable of receiving all sorts of impressions, it is not for the purpose of engraving upon it the names of kings, dates, terms in heraldry [...] but it is in order that all the ideas, which he can conceive [...] may serve him for self-conduct during his whole life (p. 79).

Rousseau echoes Locke but presses the material epistemology further by remonstrating with those educational programmes which insist upon 'engraving' useless historical facts upon the 'child's brain.' If, as The Spectator claimed, the child is like marble, then the pedagogue has the capacity to ruin the quality of the stone as much as he has the capacity to polish and refine the block into a well-formed adult.

Rousseau plays with this materiality as part of his discussion of the transferal of knowledge:

It is said that Hermes engraved on columns the elements of the sciences in order to protect his discoveries from the deluge. If he had thoroughly imprinted them in the heads of men they would have been preserved there through tradition. Well-prepared brains are the monuments on which human knowledges are most permanently engraved (p. 162).

While in Book 2 information is relayed to the child by 'engraving' pointless heraldic terms, in Book 3 Rousseau laments the fact that worthwhile 'elements of the sciences' have not been 'permanently engraved' on the collective consciousness of mankind. In both instances, information is seen to be part of a mechanical process whereby the pedagogue is tasked with filling in the blanks of the child's brain-writing upon Locke's tabula rasa as it were-to produce 'a store-house of knowledge' (p. 80). By Book 4, if Rousseau is able to observe in his protégé ' $\mathrm{t}$ ] he true principles of the just, the true models of the beautiful [...] engraved in his understanding' (p. 229) (emphasis added), this is only because the attentive pedagogue has been judicious in the choice of objects and in the choice of experiences, which have been permitted to the pupil (pp. 79-80).

Far from supporting a self-led pedagogical programme, the language in Emile betrays an authoritative and dogmatic approach, which is dependent upon physical metaphors to describe psychological phenomenon. What's more, Rousseau envisages a pedagogue akin to a Pygmalion sculptor, whereby the child is shaped and moulded into an idealised form: 'I will press him to my heart while shedding over him tears of tenderness, and I will say to him: 'You are my all, my child, my workmanship" (p. 239). Of course, if this process is mishandled then a monster, rather than a model, is produced.

If, then, eighteenth-century parents were expected to become educational facilitators, and if Rousseau is so definite in his declaration that the father should act as 'the real preceptor' ( $p$. 15), why did he fail to educate his own children? It is this question that specifically piques both Shelley and Blake, and which brings Shelley to refer to Rousseau's actions as 'criminal' 25 and Blake to call his Confessions a 'cloke for his sin' ( $J 738$ ii.52.55). In fact, one of the reasons for Victor Frankenstein's illfated project in Frankenstein is because he lacked a paternal pedagogue to guide his youthful interests; for, while Victor shows a predilection for natural philosophy, his journey into charnelhouses results from his father's inattention.

Victor acknowledges that, as he was 'self-taught,' he was 'left to struggle with a child's blindness' (2003, p. 42). He claims that 'Natural philosophy is the genius that has regulated my fate' (p. 40), but this is only set in motion by the father's inability to carry out his duty. Both the mariner Walton, whose letters frame Frankenstein, and Victor's creature voice similar concerns. Walton claims that his daydreams have begun to run wild, and that he requires 'a friend who would have sense enough [...] to regulate my mind' (p. 20), and the creature complains, 'where were my friends and relations? No father had watched my infant days, no mother had blessed me with smiles and caresses' (p. 124).

Mary Poovey has noted that Shelley, like contemporary Lockean philosophers, 'asserts that circumstances activate and direct an individual's capacity for imaginative activity; the inclination [...] thus formed then constitutes the basis of identity' (1980, p. 334). The desires stirred in childhood form the adult's character, but this ontological foundation can become a perverted idolatry of its original enthusiasm: operating according to its own impetus, childhood desires become adult obsessions. Mary Shelley therefore characterises Victor's predilection for natural philosophy as the origin of a malevolent fervour and his imagination as primarily egotistical. It is only through 'the give-and-talk of domestic relationships' that such ambitions can be regulated.

At first, Victor recounts how his curiosity was piqued:

The world was to me a secret, which I desired to divine... earnest research to learn the hidden laws of nature, gladness akin to rapture, as they were unfolded to me, are among the earliest sensations I can remember (p. 38).

Rousseau, too, tells his readers to make their pupils 'attentive to natural phenomena' and to nourish this 'curiosity' by '[a]sk[ing] questions that are within his comprehension, and leave him to resolve them' (1918, p. 137). Victor, like Rousseau's idealised pupil, searches nature to uncover its 'hidden laws,' but whereas Rousseau's pupil has an attentive pedagogue, Victor is alone.

Victor's pronominal language highlights his isolation: ' $t$ ] he world was to me a secret, which $I$ desired to divine,' 'the hidden laws... were unfolded to me,' and these pleasant memories 'are among the earliest sensations $I$ can remember' (emphasis added). Victor single-mindedly pursues his interests, driven by a personal/egotistical drive 'to divine' nature's laws.

Having stumbled upon a volume of Agrippa at an inn near Thonon, Victor's 'father looked carelessly at the title page of my book and said, 'Ah! Cornelius Agrippa! My dear Victor, do not waste your time upon this; it is sad trash" (p. 40). Victor is clearly put out by his father's rejection, but this only makes him more determined to delve into the works of Paracelsus and Albertus Magnus (p. 41). These natural philosophers then become Victor's 'new preceptors' (p. 42) and occupy the vacant role of the paternal pedagogue.

Additionally, it is also worthwhile noting that while in the 1818 edition of the text it is the father who explains to his son that the tree struck by lightning has been brought low by 'Electricity,' in the 1831 revision it is 'a man of great research in natural philosophy' who explains 'electricity and galvanism' and thereby 'threw greatly into the shade Cornelius Agrippa, Albertus Magnus, and Paracelsus, the lords of my imagination' (pp. 42-3). The latter version makes the father's initial dismissal of Agrippa even more pivotal for he is thereafter unable to obviate his fault.

Because of his father's pedagogical carelessness towards him in youth, Victor isolates himself in later life-exemplified by his solitary research at Ingolstadt-and secretes the things he should share in the safe sphere of filial relationships deep within his own soul. Victor turns inwards like many Romantic egotists, shunning the outward universalising tendency advocated by Percy Shelley in A Defence of Poetry. Indeed, as Victor takes leave of his family and travels to university, he claims: 'I was now alone... whither I was going, I must form my own friends' (p. 46). ${ }^{26}$ 
Frankenstein's creature similarly pinpoints his isolation as a corrupting influence: 'Believe me, Frankenstein: I was benevolent; my soul glowed with love and humanity,' he attests, 'but am I not alone, miserably alone' (2003, p. 103). Then, while watching the De Laceys, the creature complains 'I required kindness and sympathy... I did not believe myself unworthy of it' (p. 134). Like his creator, the creature requires a moderator to guide the otherwise wayward mind from the doubts which arise from private reflection. Far from advocating the segregation of pupils, like the experimental approach taken to Émile's education, Shelley is warning her readers about the dangers of withdrawing from society.

The creature, having learnt to read from his time at the De Laceys' cottage, continues his self-led education with John Milton's Paradise Lost, a volume of Plutarch's Lives, and Johann Wolfgang von Goethe's Sorrows of Werther. These texts produce in the creature 'an infinity of new images and feelings' that raise him both 'to ecstasy' as well as sink him 'into the lowest dejection.' He begins to speculate upon 'what had hitherto been to me obscure subjects,' though finds these thoughts aroused 'a neverending source of speculation and astonishment' (pp. 130-1). Like Victor who, after reading his books on natural philosophy, came away 'discontented and unsatisfied' (p. 41), the creature is left perplexed (p. 131). Such is the creature's ontological restlessness that the narrative descends into a barrage of abstract questioning: 'What did this mean? Who was I? What was I? Whence did I come? What was my destination?' As the creature admits, ' $[\mathrm{t}]$ hese questions continually recurred, but I was unable to solve them.'

Cutoff from the tender influence of a father, and beyond the corrections of a pedagogue, the creature is driven to find a mate as a companion:

I swear to you, by the earth, which I inhabit, and by you that made me, that with the companion you bestow I will quit the neighbourhood of man, and dwell, as it may chance, in the most savage of places. My evil passions will have fled, for I shall meet with sympathy! (p. 149).

The creature's language, however, descends into a teleological redundancy. He believes that by creating an Eve for the alreadyfallen Adam a prelapsarian existence can (re)commence away from the societal and political structures of the postlapsarian world. Of course, this is impossible, as much as it is impossible for a Blakean character to return to the State of Innocence once they've progressed to the State of Experience, ${ }^{27}$ and the creature's anger at Frankenstein's refusal evidences his true nature:

If I have no ties and no affections, hatred and vice must be my portion... My vices are the children of a forced solitude that I abhor; and my virtues will necessarily arise when I live in communion with an equal [...] and become linked to the chain of existence and events, from which I am now excluded (p. 150).

The creature abhors his figurative 'children' because they are the 'vices' bred from 'solitude.' While Alphonse Frankenstein neglected to direct his son's studies (pp. 40-1), the creature's selftaught education fills his head with Miltonic rebellion (p. 132), the melancholia of Werther (pp. 130-1), and the 'high thoughts' from Plutarch (p. 131): 'I ought to be thy Adam,' he complains, 'but I am rather the fallen angel, whom thou drivest from joy for no misdeed' (p. 103). ${ }^{28}$ Instead of regulating those new emotions, the creature's sensitivity is further heightened after reading Victor's scientific journal (p. 132). The creature sinks deeper into 'despondency and solitude,' crying out ' $[w]$ hy did you form a monster so hideous that even you turned from me in disgust?' (p. 133). Feeling once more the bitterness of the child's abandonment by the biological father, the creature accepts Plutarch, Milton, and Goethe as his literary fathers. $^{29}$

Mary Shelley draws Rousseau's pedagogical practice to its fatal conclusion: the isolated child shaped by a self-led educational programme will succumb to the cacophony of his own thoughts and feelings. ${ }^{30}$ Furthermore, Rousseau's concerns about the correlation between a malformed body and a weak institution is perhaps most vividly articulated through the creature, which was made from the 'collect[ion] of bones from charnel-houses' (2003, p. 55). ${ }^{31}$ As John Locke warns, 'Let Nature have scope to fashion the Body as she thinks best; she works of her self a great deal better, and exacter, than we can direct her,' adding that 'if Women were themselves to frame the Bodies of their Children in their wombs [...] we should as certainly have no perfect children born' (1693, p. 10). Rousseau similarly opens Émile with the declaration that ' $[\mathrm{e}]$ verything is good as it comes from the hands of the Author of Nature; but everything degenerates in the hands of man' (1918, p. 1). In fact, although Victor took 'such infinite pains and care' and believed his creature's 'limbs were in proportion' and that 'his features [were] beautiful' (p. 58), he ends up cursing 'the hands that formed you!' (p. 104).

Los, in Blake's The Book of Urizen, is employed in a similar task of creation, binding 'the formless unmeasurable death' (BU 247 7.9) of Urizen's fallen spirit before ossifying 'every change/With rivets of iron \& brass' (8.10-1). Los continues by 'forging chains new \& new' (248 10.17), creating 'A vast Spine' (p. 37), 'Ribs, like a bending cavern' (pp. 249 39), and 'bones of solidness' (p. 40). The rest of Chapter IV[b] follows the formation of Urizen's heart, brain, eyes, ears, nostrils, stomach, tongue, and limbs, detailing the fall into corporeality of the once spiritual beings. Then, like Victor who ' $[\mathrm{u}]$ nable to endure the aspect of the being I had created [...] rushed out of the room' (2003, p. 58), Los is unable to look upon the physical manifestation of his creative labour: 'In terrors Los shrunk form his task: /His great hammer fell from his hand' (250 13.20-1).

Although Urizen is not Los' child-Urizen is a separated portion of Los himself 'rent from his side' (246 6.4) - his treatment of, and reaction to, Urizen's newly formed physical existence is a foreshadowing of his future relationship with his son, Orc. In fact, although the creature, which Victor brings to life in Frankenstein is not his biological child either, there are similar parallels between Victor-as-creator and Alphonse-as-father. For example, there's something not altogether pleasant in Victor's self-identification as his parent's 'plaything' when he remembers his 'father's smile of benevolent pleasure':

I was their plaything and their idol, and something bettertheir child, the innocent and helpless creature bestowed on them by Heaven, whom to bring up to good, and whose future lot was in their hands [...] according as they fulfilled their duties towards me (2003, p. 35).

The opportunity to rectify his father's failure is, in part, what drives Victor's scientific activity which is, from the start, firmly couched in the semantics of family life: 'A new species would bless me as its creator... No father could claim the gratitude of his child so completely as I should deserve theirs' (p. 55). Indeed, Victor's language echoes that of The Female Spectator no. 7 (1745):

Our Parents, as next to Heaven the Authors of our Being, and Protectors of our helpless Infancy, certainly claim the first and greatest share of our Love and Gratitude... Love and Respect to them are Duties so known and universally confessed, that where a Person is visibly wanting in either of these, he is deservedly looked upon as a Monster (1755, p. 37). 
Victor, as I have argued, blames his father for not 'tak[ing] the pains to explain [...] that the principles of Agrippa had been entirely exploded' and for failing to teach him 'a modern system of science' (p. 40). Indeed, Victor isolates this moment as the catalyst for 'the train of my ideas', which produced 'the fatal impulse that led to my ruin' (p. 41). His subsequent abandonment of the creature can therefore be read as a dramatic aggravation of his own father's carelessness. ${ }^{32}$

However, to return to The Book of Urizen, it is inside Enitharmon's womb where the embryonic Orc 'lay like a Worm.../ To be moulded into existence' (BU 253 19.21-3). Orc's father, Los, stands ready to shape the child's mind by 'bath[ing] him in springs of sorrow' (254 20.4), but then finds that 'A tight'ning girdle grew, /Around his [own] bosom':

In sobbings

He burst the girdle in twain,

But still another girdle

Oppressd his bosom, In sobbings

Again he burst it. Again

Another girdle succeeds

The girdle was form'd by day;

By night was burst in twain

(254 20.9-17).

The girdles fall onto a rock and form a chain, which binds Orc (18-20). Los and Enitharmon then take Orc to the top of a mountain where 'They chain'd his young limbs [...] With the Chain of Jealousy/Beneath Urizen's deathful shadow' (23-5). Rousseau warned his readers in Emile how nurses were prone to mould infants' heads, but Los and Enitharmon fail to correct these harmful practices. What's more, Blake recycles Rousseau's penal imagery as Los and Enitharmon bind their son with the Chain of Jealousy, a malicious link which infiltrates the relationship between father and son, mother and son, as well as between father and mother.

Committed 'Beneath Urizen's deathful shadow,' the chaining of Orc sets a precedent for future filial relationships:

Urizen sicken'd to see

His eternal creations appear

Sons \& daughters of sorrow

(255 23.8-10).

This scene is repeated in 'Night the Fifth' of The Four Zoas, where Enitharmon gives birth to 'a terrible Child' (FZ 346 v.58.17). Los turns his back on Orc and instead starts building Golgonooza, the city of art. After 14 years, Los returns to his son but 'beheld malignant fires/In his young eyes discerning plain that Orc plotted his death' (8-9). Once more, Los is overcome with grief and once amore 'a tightening girdle grew/Around his bosom like a bloody cord' (10-1), whereupon Los takes his son to the top of a mountain and, after binding him with the Chain of Jealousy, crucifies him to the spot (pp. 348-9 19-30).

Once Orc is fastened, his 'rage flamed tenfold forth rending/ Roaring redounding. Loud Loud Louder \& Louder' (349 61.2-3), scaring his parents 'down into the deeps \& into his [Los'] labyrinth' (8). Los and Enitharmon flee from the monster they have created, following a subterraneous passage back to Golgonooza where they 'Felt all the sorrow Parents feel' (351 62.10). It is at this point that Los repents and promises to release his son. However, when he arrives at the mountaintop:

Lo the young limbs had strucken root into the rock \& strong

Fibres had from the Chain of Jealousy inwove themselves...

In vain they strove now to unchain. In vain with bitter tears

To melt the chain of Jealousy

(22-7).

Los' mistreatment of his son cannot be undone: the father's inhumanity, his monstrosity, has twisted and perverted the human form until the Chain of Jealousy 'became one with him a living Chain' (352 63.3).

In the early narrative poem Tiriel, Blake addresses a similar concern. The aged monarch Tiriel blames his sons for the death of his wife, Myratana, as well as his own demise: 'Serpents not sons. wreathing around the bones of Tiriel/Ye worms of death feasting upon your aged parents flesh' ( $T 86$ 1.22-3). As a last act of cruelty, Tiriel curses his sons (p. 87 43-51) before he takes his leave to find the vales of Har. He spares his daughter, Hela, but fearing that she will disobey his commands, reminds her of her 'fathers curse/That thou shalt feel worms in thy marrow creeping thro thy bones' (20-1).

Hela condemns Tiriel as 'cruel,' an 'avenger' (p. 99 23), and the 'murderer of thy helpless children' (p. 100 35). In retaliation, Tiriel curses his daughter so that 'snakes rise from thy bedded locks' (43). While at the beginning of the poem Tiriel's identification of his sons as 'serpents' was metaphorical, his language increasingly takes on the creative quality of being able to manifest it physically.

The material reality of the individual's psychological state is further emphasised at the end of the poem where, having made it to the vales of Har, Tiriel complains that he has become 'subtil as a serpent in paradise' and that this 'paradise is falln \& a drear sandy plain / Returns my thirsty hissings in a curse' (p. 103 8.37-40). Tiriel is only 'subtil as a serpent,' but thereafter his environment takes on the aesthetics of the 'paradise' to which he referred as part of the original metaphor. He himself becomes the snake, whereupon the 'sandy plain' of his new existence 'Returns my thirsty hissings.'

For Blake, the individual's mental state affects reality as we perceive it as part of the external world. Indeed, the relationship between the body and mind provides a thematic marker for his entire mythopoeia. In Tiriel's last speech, Blake continues by combining Locke's epistemological foundation with Rousseau's warning about the intellectual consequences of somatic mishandling:

And why men bound beneath the heavens in a reptile form

A worm of 60 winters creeping on the dusky ground

The child springs from the womb. the father ready stands to form

The infant head while the mother idle plays with her dog on her couch...

The father forms a whip to rouze the sluggish senses to act 
And scourges off all youthful fancies from the newborn man

\section{(p. 103 8.23-30).}

The syntax allows for an anthropological progression of the 'reptile form' into 'A worm,' 'The child,' 'the new-born man,' and eventually into a 'drone' (33). The evolutionary perversion of the child's maturation maps his mistreatment at the hands of his parents: from birth, the child is moulded by the father who shapes 'The infant head' physically and psychologically.

Blake accentuates this dual application (emphasised by the homonymic noun 'form' and verb 'to form') through the metaphor of the father's 'whip', which is made 'to rouze the sluggish senses to act.' The mental faculties, susceptible to physical force, are malformed by the tyrannical father who circumscribes freedom of movement and freedom of thought in order to bend the child's will to his own: 'Then walks the weak infant in sorrow compelled to number footsteps' (31).

Blake agrees with Rousseau that this practice is not only detrimental to the physical well-being of the child but also inhibits intellectual growth. However, while Rousseau implicates nurses, Blake attacks the father who combines such physical malformation with psychological repression:

[Tiriel] evolves from an infant whose desire for love and nurture turns to envious rage through maternal neglect, to the child whose fantasies are repressed by the father, to the rebellious son, and finally to the cursing father-figure, who will cause the pattern to be repeated in the next generation

(Webster, 1983, p. 47).

The neglected child becomes a neglectful father who perpetuates a chain of monstrous behaviour, which ruins the moral state of the family and, as an aftereffect, the welfare of society. By implying that when the child is born the senses are activated solely through 'difficulty \& pain,' Blake is conflating the roles of the nurse and the father: physical mistreatment leads to psychological degeneration which creates the monstrous 'new-born man.'

The incompetence of the father illustrates for Blake that the experience of adulthood is no guarantee of a spiritual superiority to the innocence of childhood. Perhaps one of Blake's biggest concerns with Rousseau's pedagogical philosophy is the refusal to allow children intellectual distinction, specifically the capacity to intuit the spiritual dimensions of life. ${ }^{33}$ In particular, Blake attacked the segregation and ideological separation of children from adults. As Frances Ferguson notes, '[ $t$ ] he Rousseauvian stages that Blake so derisively called 'ratios' accorded a child reason by segmenting the child's reason out of a nearly universal reason' (2003, p. 217). Indeed, while Rousseau stresses physical and psychological freedom, this freedom is limited to the epistemological framework of the child's (un)intellectual mind.

This is evidenced in Emile where Rousseau challenges Locke's 'grand maxim' that we should 'reason with children':

Of all the faculties of man, reason [...] is that which is developed with the most difficulty and the latest... The master-work of a good education is to make a reasonable man, and we propose to train up a child through the reason! That is to begin at the end (pp. 52-3). ${ }^{34}$

For Rousseau, the child is unreasonable because his formative years are bound to a tender frame which is only able to support a weak intuition: ' $\mathrm{w}$ ]e are born weak; we have need of strength: we are born destitute of everything; we have need of assistance: we are born stupid; we have need of judgement' (p. 2). ${ }^{35}$ Blake disagrees. The child's spiritual capacity is not diminished simply because he is a child. ${ }^{36}$ Nevertheless, if Rousseau is adamant that the physical well-being of the infant's body is a prerequisite for intellectual stimulation, then his dereliction of duty-with regards to his own children-makes him 'guilty of a crime' (prefiguring Shelley's own accusation):

He who cannot fulfil the duties of a father has no right to become such. Neither poverty, nor business, nor fear of the world, can excuse him from the duty of supporting and educating his own children. (p. 16). ${ }^{37}$

In Confessions, Rousseau 'thank[s] heaven for having preserved them [his children] from their father's destiny' (2000, p. 348), yet his own experiences, especially witnessing the degeneration of his brother, do not sit comfortably with his decision to leave his children to an orphanage. While Rousseau is confident that he has saved them from the negative influence of Thérèse's family and the ill-suited charge of Mme d'Épinay and Mme de Luxembourg (pp. 347-8), ${ }^{38}$ Blake and Shelley both demonstrate how he had potentially delivered them up to a far worse fate.

Received: 19 March 2019 Accepted: 24 June 2019

Published online: 16 July 2019

\section{Notes}

1 Hogle, 2016, 45-6. Shelley would also have come across her mother's reactions in A Vindication of the Rights of Woman (1792). Shelly read both her parents' works during her courtship with Percy Shelly (Clemit, 2003, p. 30).

2 The Penguin edition cited is based on the 1831 text.

3 Bloom, 1987, pp. 2-4; Clemit, 2003, p. 33; Giddey, 2004, p. 77.

4 David V. Erdman traces some of Blake's nomenclature to Rousseau's Discourse on Inequality and Émile (1977, p. 252). Nicholas Williams argues that Rousseau provides 'the backdrop for Blake's composition of the Songs' (1985, p. 38). Zachary Leader finds Rousseauvian echoes in Tiriel (1981, pp. 23-4). It is likely that Blake was familiar with Henry Fuseli's Remarks on Rousseau (Erdman, 1977, p. 428). Kathleen Raine also suggests that Blake became acquainted with Rousseau's philosophy through Mary Wollstonecraft (1991, p. 47). Through the bookseller Joseph Johnson, Blake engraved plates for Wollstonecraft's translation of C. G. Salzman's Elements of Morality (1790) and Original Stories (1791).

5 Blake classes Rousseau 'among the villains of his milieu' (Quinney, 2009, p. 20).

6 John Howard reads Milton 22.41 as a direct reference to Rousseau's Confessions (1976, p. 109; 273)

7 While Stewart Crehan argues that Blake's 'new-found libertarian ideas' were 'fired by his reading of Rousseau' (1984, p. 110), he admits in his analysis of Jerusalem that '[i]t is Voltaire and Rousseau who are the real hypocrites' (p. 319). Leonard Deen similarly observes a turning away in the latter prophecies (1983, pp. 78-9). As Leo Damrosch points out, Blake 'saw both Voltaire and Rousseau as believers in natural religion' (2015, p. 121). The coupling of Voltaire and Rousseau was not uncommon in England (Howard, 1976, p. 136).

8 Pamela Clemit observes in Victor's treatment of his creature 'parallels with Rousseau's life story' (2003, p. 34), while Nicholas Williams notes how both Rousseau and Blake are concerned with the 'way in which seemingly caring [...] voices come to serve $[\ldots]$ a more explicitly repressive social system' (1985, p. 45).

9 See, for example, John Beer's Romantic Consciousness: Blake to Mary Shelley (2003). See also Cantor (1985, ix) and Lussier (2000, p. 166).

10 Cantor 1985, ix-x; Bloom, 1987, pp. 2-10; Sherwin, 1987, pp. 40-3; Lussier, 2000, pp 166; 172; Cooper, 2013, p. 219.

11 The creature is 'for one Romanticist a Blakean "spectre," for another a Blakean "emanation" (Sherwin, 1987, p. 40).

12 See Leader (1981, pp. 1-36) and Williams (1999, pp. 32-70) for Rousseau's influence on Blake's Songs. David V. Erdman writes that the 'Preludium' of America was a variation on the opening of Rousseau's Social Contract $(1977$, pp. $258 ; 265)$ and that Visions of the Daughters of Albion and The Book of Urizen are also indebted to Rousseau (p. 259)

13 See Richardson (1989, p. 853), Dennis (2011, p. 204), and Leader (1981, pp. 22; 178) for the significance of Locke and Rousseau to this debate.

14 Simon, 1979, p. 63.

15 John Adamson claims Francis Bacon as 'the one man who set the thoughts of many [...] upon school reform' (1921, p. 17). Joan Simon notes that '[i]n republican England after $1640[\ldots]$ parliament seriously considered plans for educational reform on Baconian lines' (1979, p. 396). 
16 For the importance of Descartes' mathematical pedagogy to educationists, see Jones (2006, pp. 48-52).

17 'A $\mathrm{A}]$ vigorous correspondence was being carried on between Comenius and those who held similar views in England' (Freeman, 1961, p. 132).

18 Richard Greaves groups Milton with Comenius and Locke as the three big seventeenth-century educational theorists (1969, p. 166).

19 The Spectator diverges from Locke's tabula rasa theory, for it presupposes innate qualities. However, Locke himself is contradictory in this regard, for he admits that there are 'various Tempers, different Inclinations, and particular Defaults, that are to be found in Children' and that 'there are possibly scarce two Children, who can be conducted by exactly the same method [of education]' (p. 261).

20 Rousseau references Some Thoughts in his preface. He also echoes Locke's tabula rasa theory at the end of Book 1 (p. 40).

21 In Emile, Rousseau refers to 'the Republic of Plato' as 'the finest work on education ever written' (p. 6).

22 Educational reformers rejected the institutionalisation of children in orphanages 'on the grounds that they were a financial burden to the state as well as detrimental to the life and well-being of the children' (Fuchs, 1984, p. 31). Rousseau, again, appears to be aware of this when he acknowledges that he has 'hand[ed] over my children to be raised at public expense' (p. 348).

23 Rousseau attempts to soften ' $[\mathrm{t}]$ he extreme affection that was lavished upon me' by admitting that his brother was only 'a little neglected' (p. 9) but the diminutive modifier rings hollow.

24 Rousseau would also have come across similar imagery in the works of his French contemporaries, such as Julien Offray de La Mettrie who in Man a Machine (1747) wrote that 'Man is not moulded from a costlier clay; nature has used but one dough, and has merely varied the leaven' (1912, p. 117). In England, Joseph Glanvill had described childhood as 'the melted wax [...] capable of any impression from the document of our Teachers' (1665, p. 95), while John Theobald was also comparing children to a 'dough' that was 'susceptible of all impressions' in the prefatory pages of The Young Wife's Guide in the Management of Her Children (1764). Theobald states that a robust child would become sickly through mismanagement, but that a sickly child could also become robust through the right management. From the late 1740s, there was a growing medical attention to the 'preservation,' 'management,' and 'physical education' of children (Benzaquen, 2006, p. 24).

25 qt. O'Rourke, 1989, p. 545.

26 Victor's secretive project replicates Urizen's 'silent activity' (BU 243 3.18-2).

27 In the 'Geneva Manuscript,' Rousseau writes that 'nature's gentle voice is no longer an infallible guide for us, nor is the independence we have received from her a desirable state... the happy life of the golden age was always a state foreign to the human race' (1978, pp. 158-9).

28 At times the creature self-identifies as either Adam (pp. 103, 132, 134) or Satan (pp. 132-3). Paul Sherwin refers to the creature as 'a freakish hybrid of Milton's Adam and Satan' (1987, p. 40)

29 'Through the books he reads, he discovers [...] his intellectual parents,' writes Anne McWhir. 'In a sense he is twice made-first through Frankenstein's macabre piercing together of fragments from the grave, then through the textual construction of his own sense of self (1990, p. 74).

30 Blake, too, maps out the monstrous consequences of the individual's withdrawal from society and reliance upon books in The Book of Urizen, where Urizen sits 'alone' and writes 'in books formd of metals' his laws under which future generations will suffer (BU 244-5 4.24-40)

31 In an anthropological articulation of this moral development, The Spectator no. 246 (12th December 1711) and no. 408 (18th June 1712) claim that a child fed upon goat's milk with assume that animal's uneven temper.

32 'Frankenstein's rejection of his creature makes him guilty of a crime that made Rousseau notorious: parental abandonment' (Clemit, 2003, p. 34). As Judith Weismann declares, 'there is hell to pay, in Frankenstein, for the man who does not put his family first' (1976, p. 180).

33 See Dennis, 2011, pp. 215-6.

34 The term 'master-work' echoes the 'workmanship' (p. 239) and other sculptural imagery throughout Émile.

35 Blake objects to Rousseau's staged ontogenesis, which is reliant upon the somatic development of 'corporeal organs': ' $t \mathrm{t}$ ] he understanding does not begin to form itself till after some years, and when the corporeal organs have acquired a certain consistence. The design of nature is therefore evidently to strengthen the body, before the mind is exercised' (1761, p. 260).

36 In fact, children's voices often critique adult discourses (Richardson, 1989, p. 865). For Blake, the child does not know less simply because he is a child because the corrupting influence of society-with David V. Erdman referring to Rousseau as 'Blake's modern source' (1977, p. 249) - may impair the adult's perspicuity and thereby lessen their spiritual receptivity.

37 There is a degree of self-admonishment and penitence when Rousseau adds, 'Reader, believe me when I predict that whoever has a heart and neglects such sacred duties will long shed bitter tears over his mistake, and will never find consolation for it.'

38 Rousseau attempts to clear himself of blame in The Reveries of the Solitary Walker: ' $\mathrm{h}] \mathrm{ad}$ I been indifferent about what would become of them, since I was incapable of raising them myself, in my situation, I would have had to let them be raised by their mother, who would have spoiled them, and by her family, who would have made monsters of them' (1992, p. 124).

\section{References}

Addison J, Richard S (1776) The spectator, Vol. 3, Edinburgh

Adamson JW (1921) Pioneers of modern education 1600-1700. Cambridge University Press, Cambridge

Beer J (2003) Romantic consciousness: Blake to Mary Shelley. Palgrave Macmillan, Basingstoke

Benzaquen Adriana S (2006) The doctor and the child: medical preservation and management of children in the eighteenth century. In: Muller Anja (ed) Fashioning childhood in the eighteenth century: age and identity. Ashgate, Aldershot, pp 13-24

Blake W (2004) William Blake: the complete poems. Penguin Books Ltd, London

Bloom H (1987) Introduction. In: Harold Bloom (ed) Modern critical interpretations: Mary Shelley's Frankenstein. Chelsea House Publishers, New York, NY, Philadelphia, pp 1-12

Chalmers A et al. (1822) The Tatler, Vol. 3. Printed for F. C. and J. Rivington, London

Clemit P (2003) Frankenstein, Matilda, and the legacies of Godwin and Wollstonecraft. In: Esther Schor (ed) The cambridge companion to Mary Shelley. Cambridge University Press, Cambridge, pp 26-44

Coleman P (2000) Introduction. In: Scholar Angela (ed) Confessions. Oxford University Press, Oxford, pp vii-xxix

Cooper Andrew A (2013) William Blake and the productions of time. Ashgate, Farnham, Burlington

Erdman DV (1977) Blake: prophet against empire. Dover Publications, Inc, New York, NY

Ferguson F (2003) The afterlife of the romantic child: Rousseau and Kant Meet Deleuze and Guattari. South Atl Q 102(1):215-234

Freeman CB (1961) A puritan educator: Hezekiah Woodward and his "Childes Patrimony". Br J Educ Stud 9(2):132-142

Fuchs RG (1984) Abandoned children: foundlings and child welfare in nineteenthcentury france. State University of New York Press, Albany

Giddey E (2004) "A meteor in the sky of literature": Byron and Switzerland. In: Cardwell A (ed) The reception of byron in Europe, Volume I: Southern Europe, France, and Romania. Thoemmes Continuum, London and New York, NY, pp 71-79

Glanvill J (1665) Scepsis scientifica... in an essay of the vanity of dogmatizing.... Printed by E. Cotes, for Henry Eversden at the Gray-Hound in St. Paul's Church-yard, London

Greaves Richard L (1969) Gerrard Winstanley and educational reform in Puritan England. Br J Educ Stud 17(2):166-176

Haywood E (1755) The female spectator. Vol. II. Printed for T. Gardner, London

Haywood E (1999) Selections from the female spectator. Oxford University Press, New York, NY and Oxford

Hogle Jerrold E (2016) Romantic contexts. In: Smith Andrew (ed) The Cambridge companion to Frankenstein. Cambridge University Press, Cambridge, pp $41-55$

Jones Matthew L (2006) The good life in the scientific revolution: Descartes, Pascal, Leibniz and the cultivation of virtue. The University of Chicago Press, Chicago and London

Leader Z (1981) Reading Blake's Songs. Routledge, London and New York, NY, 2016

Locke J (1693) Some thoughts concerning education. Printed for A. and J. Churchill at the Black Swan in Paternoster-row, London

Lussier Mark S (2000) Romantic dynamics: The poetics of physicality. Macmillan Press Ltd, London

McWhir A (1990) Teaching the monster to read: Mary Shelley, Education and Frankenstein. In: Willinsky John (ed) The educational legacy of romanticism. Wilfrid Laurier University Press, Waterloo, ON, pp 73-92

Nichols Mary P (1985) Rousseau's novel education in the emile. Political Theory 13 (4):535-558

O’Rourke J (1989) "Nothing more unnatural": Mary Shelley's revision of Rousseau. ELH 56(3):543-569

Poovey M (1980) My hideous progeny: Mary Shelley and the feminization of romanticism. PMLA 95(3):332-347

Quinney L (2009) William Blake on self and soul. Harvard University Press, Cambridge

Richardson A (1989) The politics of childhood: wordsworth, blake, and catechistic method. ELH 56(4):853-868

Rousseau J-J (1761) A discourse upon the origin and foundation of the inequality among mankind. Printed for R. and J. Dodsley, in Pallmall, London

Rousseau J-J (1918) Émile; or, treatise on education. Trans. Payne William H. D. Appleton and Company, New York and London

Rousseau J-J (1992) The reveries of the solitary walker. Trans. Butterworth Charles E. Hackett Publishing Company, Indianapolis and Cambridge 
Rousseau J-J (2000) Confessions. Trans. Scholar Angela. Oxford University Press, Oxford

Shelley M (2003) Frankenstein. Penguin Books Ltd, London

Sherwin P (1987) Frankenstein: Creation as Catastrophe. In: Harold Bloom (ed) Modern Critical Interpretations: Mary Shelley's Frankenstein. Chelsea House Publishers, New York, NY, Philadelphia, pp 27-54

Simon J (1979) Education and society in tudor England. Cambridge University Press, Cambridge

Theobald J (1764) The young wife's guide in the management of her children. Printed and sold by W. Griffin, R. Withy, G. Kearsley, and E. Etherington, at York, London

Webster Brenda S (1983) Blake's prophetic psychology. The University of Georgia Press, Athens, Georgia

Weissman J (1976) A reading of Frankenstein as the complaint of a political wife. Colby Lit Q 12:171-180

Welch Dennis M (2011) Blake and Rousseau on. Child's Read, Pleas, Imagin Lion Unic 35(3):199-226

Williams N (1999) Ideology and Utopia in the poetry of William Blake. Cambridge University Press, Cambridge

\section{Additional information}

Competing interests: The author declares no competing interests.
Reprints and permission information is available online at http://www.nature.com/ reprints

Publisher's note: Springer Nature remains neutral with regard to jurisdictional claims in published maps and institutional affiliations.

(c) (i) Open Access This article is licensed under a Creative Commons Attribution 4.0 International License, which permits use, sharing, adaptation, distribution and reproduction in any medium or format, as long as you give appropriate credit to the original author(s) and the source, provide a link to the Creative Commons license, and indicate if changes were made. The images or other third party material in this article are included in the article's Creative Commons license, unles indicated otherwise in a credit line to the material. If material is not included in the article's Creative Commons license and your intended use is not permitted by statutory regulation or exceeds the permitted use, you will need to obtain permission directly from the copyright holder. To view a copy of this license, visit http://creativecommons.org/ licenses/by/4.0/.

(C) The Author(s) 2019 